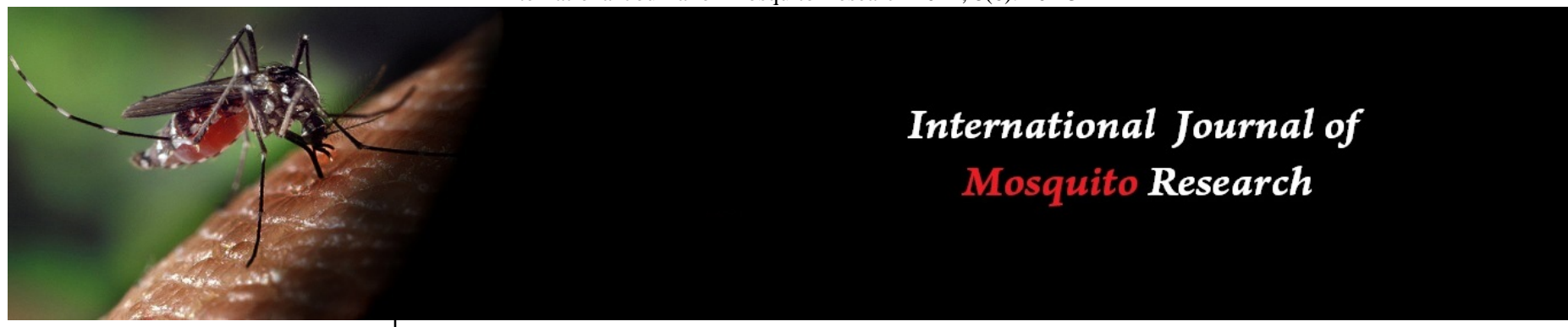

ISSN: 2348-5906

CODEN: IJMRK2

IJMR 2021; 8(6): 20-23

(C) 2021 IJMR

www.dipterajournal.com

Received: 25-08-2021

Accepted: 14-10-2021

\section{Lekshmi R}

Post Graduate, Department of Zoology and Research Centre, Mahatma Gandhi College,

Thiruvananthapuram, Kerala, India

\section{Adhira M Nayar}

Post Graduate, Department of Zoology and Research Centre, Mahatma Gandhi College,

Thiruvananthapuram, Kerala, India

\section{Sumodan PK}

Post Graduate and Research, Department of Zoology, Government College, Madappally, Vadakara, Kerala, India
Corresponding Author: Sumodan PK

Post Graduate and Research

Department of Zoology,

Government College,

Madappally, Vadakara, Kerala, India

\section{A rapid entomological reconnaissance during the first Zika outbreak in Thiruvananthapuram city, Kerala, India}

\author{
Lekshmi R, Adhira M Nayar and Sumodan PK
}

DOI: https://doi.org/10.22271/23487941.2021.v8.i6a.567

\section{Abstract}

There was an outbreak of Zika virus in Thiruvananthapuram city of Kerala state, India in July 2021. In order to ascertain the prevalence and breeding pattern of the potential vectors, a study was conducted from 22 July 2021 to 27 July 2021. Breeding habitat surveys were conducted in seven localities in the city from where Zika cases were reported. House to house searches were conducted from mosquito breeding in 35-40 houses in each locality. Fourth instar larvae were identified using larval keys and later confirmed their identities after emergence. Lower instar larvae were reared in the laboratory and were identified after emergence using adult keys. Larval indices were calculated using WHO methods. Of the 280 houses surveyed mosquito breeding was encountered in 38 houses. Three Aedes species viz., Ae. aegypti, Ae. albopictus and Ae. vittatus were detected. Ae. agypti and Ae. albopictus were breeding in $30.5 \%$ and $43.9 \%$ of the outdoor habitats and $56.0 \%$ and $16.0 \%$ of the indoor habitats respectively. The overall Container Index for (CI), Breteau Index (BI) and House Index (HI) for both species together were 56.07, 23.07 and 14.61 respectively. Two established urban Zika vectors viz., Ae. aegypti and Ae. albopictus were prevalent in the city with very high container indices. For the first time in the world, indoor flower vases used for money plant has been observed as an important breeding habitat of Aedes mosquitoes. Rapid elimination of the breeding habitats with community support is recommended to reduce the larval indices.

Keywords: Zika, Aedes aegypti, Aedes albopictus, Container Index, House index, Breteau index

\section{Introduction}

The history of Zika dates back to 1947, when a new virus was detected from a Rhesus monkey in Uganda, Africa, which was later named as Zika virus after the name of the forest in which the virus was isolated. The first incidence of the virus in humans was reported in 1952 from Nigeria ${ }^{[1]}$. Although there were occasional outbreaks after the first outbreak in different parts of Africa and Asia, the disease was not considered a serious public health problem owing to its benign nature ${ }^{[2]}$. However, the re-emerged Zika, starting with Yap Island, Micronesia in 2007 which spread to French Polynesia and several South American countries, appeared more virulent causing microcephaly in infants and Guillain Barre Syndrome in adults. This led World Health Organisation to declare Zika as a Public Health Emergency of International Concern (PHEC) on 1 February 2016, on the advice of an Emergency Committee of the International Health Regulations and of other experts ${ }^{[3]}$.

The first report of the re-emerged Zika in the WHO South-Eastern Region (WHO-SEAR) was in 2012 from Indonesia ${ }^{[4]}$. In India serological evidence for the prevalence of Zika virus was available as far back as in 1952 with 33 samples out of 196 samples collected from six states turning positive. However, post re-emergence, Zika appeared in India for the first time during 2016-17. There were four cases reported from Gujarat and Tamil Nadu during that period ${ }^{5]}$. Subsequently, in 2018, there were two major outbreaks in Rajasthan and Madhya Pradesh with 153 and 130 confirmed cases respectively ${ }^{[5]}$

On $8^{\text {th }}$ July 2021 media reported a case of Zika in Thiruvananthapuram, the capital city of Kerala state. The patient was a 24 year old pregnant woman admitted in a private hospital in the city on $28^{\text {th }}$ June 2021 . She delivered a healthy baby on $7^{\text {th }}$ July 2021, a day before the confirmation of Zika. In the subsequent days more cases were reported from different parts of the city. In reply to the starred question No. 275 by the member of Parliament Shri Hibi Eden 
(available in public domain), the minister of health and family welfare, Government of India stated that there were 65 cases of Zika in Kerala as on $2^{\text {nd }}$ August 2021. 61 cases were reported from Thiruvananthapuram city and another four cases from three cities outside the city. These four cases had histories of travel to Thiruvananthapuram.

Against this background we had designed a study to investigate the prevalence and pattern of breeding of potential vectors of Zika in the city. The study was carried out from 22 July 2021 to 27 July 2021.

\section{Materials and Methods}

2.1. Study area: The study was carried out in Thiruvananthapuram, the capital city of the South Indian state Kerala. The city has an area of $214 \mathrm{KM}^{2}$ and a population of 957, 730 (2011 Census).

2.2. Larval survey: Larval surveys were conducted in seven localities in the city, viz., Nanthancode, Kannanmoola, Karamana, Chakkai, Medical college, Thycaud and Nalanchira, from where Zika cases were reported. 35-40 houses were surveyed in each locality. The number of houses surveyed varied according to the size of the premises. Overall 260 premises were surveyed. Intensive searches were conducted indoor and outdoor for larval habitats, especially containers and tanks. Only those containers/ tanks with water were considered as breeding habitats. From small containers, entire water with larvae were emptied in to plastic containers. From large tanks and barrels, five samples each were collected using $300 \mathrm{ml}$ dippers.

2.3. Identification: Fourth instar larvae were identified with larval keys ${ }^{[6]}$. Early instar larvae were reared in the laboratory and the adults were identified using adult keys ${ }^{[7]}$.
2.4. Data analysis: Container index, House index and Breteau index were calculated as recommended by World Health Organisation ${ }^{[8]}$.

\section{Results and Discussion}

3.1. Habitat diversity: Eight types of breeding habitats viz., barrels/drums, plastic tanks, cement tanks, coconut shells, discarded tyres, flower pots and minor plastic containers were encountered outdoors. Plastic tanks (28.0\%), flower pots (24.4\%) and minor plastic containers (23.2\%) were the major breeding habitats, which together formed $75.6 \%$ of the total habitats (Table-1). The indoor breeding habitats encountered were flower vases/ pots used for keeping money plants or lucky bamboos, drip trays of refrigerators and coolers, and leaf axil. Flower pots/ vases (60\%) was the topmost habitat (Table -2).

3.2. Mosquito breeding: Three Aedes species viz., Ae. aegypti, Ae. albopictus and Ae. vittatus were found breeding both indoor and outdoor. Of the 82 outdoor habitats Ae. aegypti bred alone in 10 habitats and in combination with $A e$. albopictus in 15 habitats. Ae. albopictus was found breeding alone in 21 habitats and Ae. vittatus in one habitat. Four habitats had breeding of non-Aedine mosquitoes. There were 25 indoor habitats, of which 10 had Aedes aegypti breeding. Co-breeding of Ae. aegypti and Ae. albopictus was found in four habitats. Ae. vittatus breeding was restricted to a single habitat. While 25 (30.5\%) outdoor habitats had breeding of Ae. aegypti, 36 (43.9\%) habitats had Ae. albopictus. Among 25 indoor habitats 14 (56\%) had Ae. aegypti and 4 (16\%) had Ae. albopictus breeding. Overall percentage breeding of Aedes aegypti, Ae. albopictus and Ae. vittatus were 36.4, 37.3 and 1.87 respectively.

Table 1: Breeding pattern of Aedes mosquitoes in outdoor habitats in Thiruvananthapuram city.

\begin{tabular}{|c|c|c|c|c|c|c|}
\hline \multirow[b]{2}{*}{ Breeding Habitats } & \multirow[b]{2}{*}{$\begin{array}{c}\text { Total habitats surveyed } \\
(\%)\end{array}$} & \multicolumn{5}{|c|}{ Positive Habitats } \\
\hline & & $\begin{array}{c}\text { Ae. } \\
\text { aegypti }\end{array}$ & $\begin{array}{c}\text { Ae. } \\
\text { albopictus }\end{array}$ & $\begin{array}{c}\text { Ae aygypti }+ \text { Ae. } \\
\text { albopictus }\end{array}$ & $\begin{array}{c}\text { Ae. } \\
\text { vittatus }\end{array}$ & $\begin{array}{c}\text { Non-Aedes } \\
\text { species }\end{array}$ \\
\hline Barrels/ drums & $6(7.3)$ & & 4 & & & \\
\hline Plastic tanks & $23(28.0)$ & 3 & & 6 & 1 & 2 \\
\hline Cement tanks & $3(3.7)$ & & 2 & 1 & & \\
\hline Coconut shells & $5(6.1)$ & & 3 & & & \\
\hline Discarded tyres & $6(7.3)$ & 3 & 1 & & & \\
\hline Flower pots & $20(24.4)$ & 1 & 10 & 4 & & \\
\hline $\begin{array}{c}\text { Minor plastic } \\
\text { containers }\end{array}$ & $19(23.2)$ & 3 & 1 & 4 & & 2 \\
\hline Total & 82 & 10 & 21 & 15 & 1 & 4 \\
\hline
\end{tabular}

Table 2: Breeding pattern of Aedes mosquitoes in indoor habitats in Thiruvananthapuram city

\begin{tabular}{|c|c|c|c|c|c|c|}
\hline \multirow[b]{2}{*}{ Breeding Habitats } & \multirow[b]{2}{*}{$\begin{array}{l}\text { Total habitats } \\
\text { surveyed }\end{array}$} & & \multicolumn{4}{|c|}{ Positive Habitats } \\
\hline & & Ae. aegypti & $\begin{array}{c}\text { Ae. } \\
\text { albopictus }\end{array}$ & $\begin{array}{c}\text { Ae. aegypti+ Ae. } \\
\text { albopictus }\end{array}$ & $\begin{array}{c}\text { Ae. } \\
\text { vittatus }\end{array}$ & $\begin{array}{c}\text { Non- Aedes } \\
\text { species }\end{array}$ \\
\hline Flower vases /pots & $15(60.0)$ & 6 & & 3 & 1 & \\
\hline $\begin{array}{c}\text { Drip trays of refrigerators/ } \\
\text { coolers }\end{array}$ & $9(36.0)$ & 3 & & 1 & & \\
\hline Leaf axils & $1(4.0)$ & 1 & & & & \\
\hline Total & 25 & 10 & & 4 & 1 & 0 \\
\hline
\end{tabular}

3.3. Larval indices: Mosquito breeding was detected in 38 houses out of 260 houses surveyed. Number of positive habitats for Ae. aygypti and Ae. albopictus together was 60 out of 107 habitats surveyed . The overall Container Index
(CI), Breteau Index (BI) and House Index (HI) for both species together were 56.07, 23.07 and 14.61 respectively ((Figure-1). 


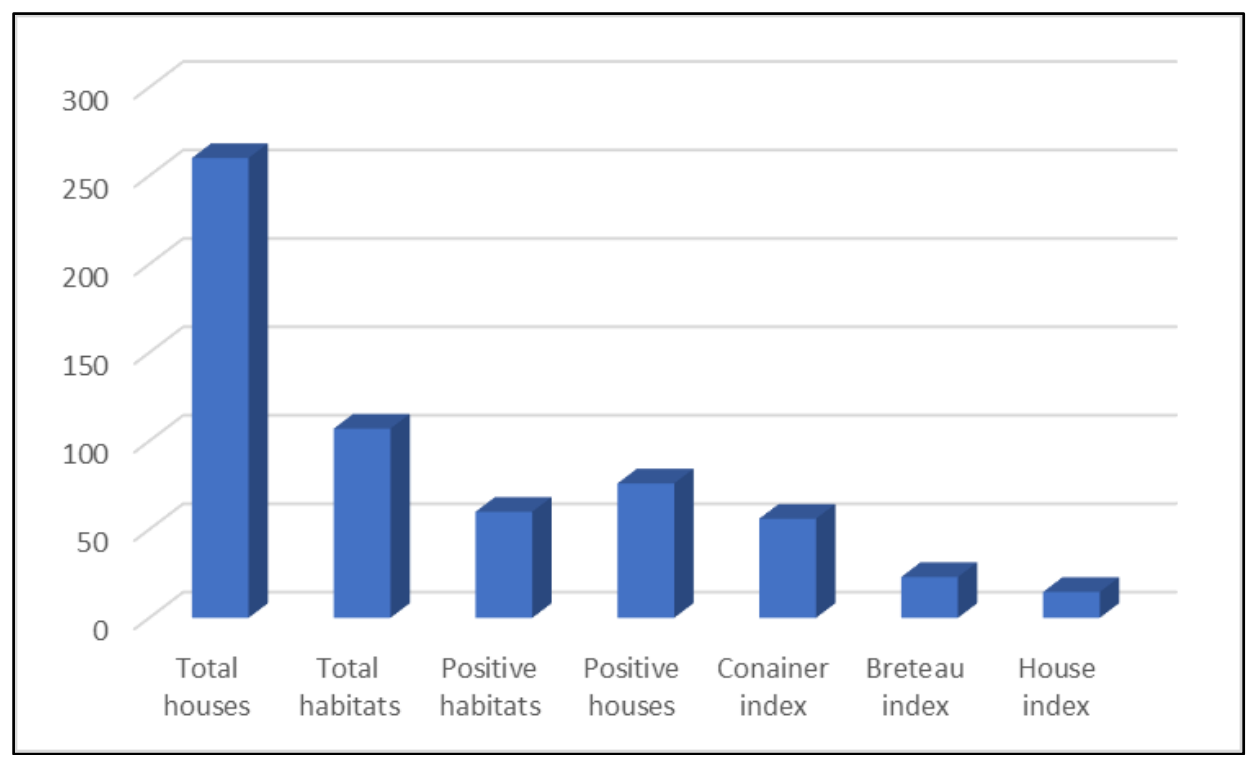

Fig 1: Breeding status of Ae. aegypti and Ae. albopictus in Thiruvananthapuram

Zika virus has two different life cycles, urban cycle and sylvian cycle. Major vectors in the urban cycles in Asia are Ae. aegypti and Ae. albopictus, with the former playing the dominant role ${ }^{[9]}$. Both species were prevalent in the study area. Ae. aegypti was the predominant indoor species occupying $56 \%$ of the breeding habitats surveyed. In the outdoor habitats, both species were prevalent with Ae. albopictus (43.9\%) exhibiting moderate edge over Ae. aegypti (30.5\%). Another interesting observation was the co-breeding of these two species both outdoor (18.3\%) and indoor (16.0\%).

Immediately after the report of the first case of Zika in Thiruvananthapuram city, an intensive drive for the elimination of Aedes breeding was launched in the city under the aegis of the Directorate of health Services, Government of Kerala. Our study started after a gap of exactly two weeks. Hence, the quantity of breeding habitats and the extent of Aedes breeding did not represent the real picture which would have existed prior to $8^{\text {th }}$ June 2021, the day when the first case was reported. Nevertheless, there were epidemiologically significant number of breeding habitats as well as Aedes breeding supported by those habitats as revealed by the high larval indices $(\mathrm{CI}=56.07, \mathrm{BI}=23.07$ and $\mathrm{HI}=14.61)$. This has exposed the lacunae in the habitat elimination drive. Ward level planning led by the elected representatives of the municipal corporation and forming sub-ward level teams for house to house search for breeding habitats and their elimination are likely to reduce the indices rapidly and effectively. Except for cement tanks, all other positive breeding habitats observed in the study area are easily disposable. Since minor plastic containers formed a significant contributor to breeding habitats, anti-plastic drive would reap collateral benefits. Cement tanks could either be demolished or larvivorous fishes can be introduced.

Another interesting observation was vector breeding in flower pots/ flower vases indoors. Refrigerators and coolers have been widely reported as important contributors for the proliferation of Ae. aegypti from many parts of India [10, 11]. Flower pots/vases were used for keeping either money plant (Epipremnum aureum) or Lucky bamboo (Dracaena sanderiana). While growing money plants is believed to improve financial status of the family, lucky bamboos are used in the Feng shui, a traditional Chinese practice, again for improving the quality of life. Though outdoor flower vases with money plants were reported to harbour Ae. aegypti and Ae. albopictus in Dhaka city, Bangladesh, their indoor prevalence has not been reported so far ${ }^{[12]}$. International trade in lucky bamboo was reported as means for the dispersal of the invasive mosquito Aedes albopictus on several occasions $[13,14]$. However, their role as breeding habitats in the context of mosquito-borne diseases have not been reported from anywhere in the world.

Kerala, being a state with very high population density and intense inter-city travelling the possibility of spread of the disease to other cities is very high. As stated in the introduction, four cases originated from the city were reported from two other cities in the state. Rapid reconnaissance and elimination of vector breeding would reduce larval indices as reported from other Zika outbreak areas in India ${ }^{[15]}$.

\section{Conclusion}

Although the first outbreak of Zika in India was reported during 2016-17, its emergence in Kerala was in July 2021. Though stray cases were reported from Tamil Nadu earlier, this was the major outbreak in South India, with 65 cases. Though Zika has not been associated with mortality, it should not be ignored as a trivial disease owing its ability to cause microcephaly in foetuses during pregnancy and Guillain Barre syndrome in adults. The present study showed the prevalence of two established vectors viz., Aedes aegypti and Aedes albopictus in Thiruvanathapuram city. They were found breeding in outdoor as well as indoor habitats. While Aedes aegypti was the predominant breeder indoors and Aedes albopictus was dominant outdoors. With well organised source reduction strategies involving the community could prevent future outbreaks in the city and elsewhere in Kerala.

\section{Acknowledgements}

The first two authors acknowledge the facilities provided by the principal, Mahatma Gandhi College, Thiruvananthapuram-695004, Kerala, India. The third author thanks the principal, Government College, Madappally, Vadakara-673102, Kerala, India. 


\section{References}

1. MacNamara FN. Zika Virus. A report on three cases of human infection during an epidemic of jaundice in Nigeria. Transactions of Royal Society of Tropical Medicine and Hygiene 1954;48(2):139-145.

2. Abushouka AI, Negidac A, Ahmed H. An updated review of Zika virus. Journal of Clinical Virology 2016;84:5358.

3. Heymann DL, Hodgson A, Sall A, Freedman DO, Staples $\mathrm{JE}$, Althabe $\mathrm{F}$ et al. Zika virus and microcephaly: why is this situation a PHEIC? Lancet 2016;387:719-721.

4. Kwong JC, Druce JD, Leder K. Zika virus infection acquired during brief travel to Indonesia. Am J Trop Med Hyg 2013;89:516-517.

5. Biswas A, Kodan P, Gupta N, Soneja M, Baruah K, Sharma KK et al. Zika outbreak in in India in 2018. Journal of Travel Medicine 2020;27(4):1-3.

6. Tyagi BK, Muniratnam A, Venkatesh A. A catalogue of Indian Mosquitoes. International Journal of Mosquito Research 2015;2(2):50-97.

7. Barraud PJ. The fauna of British India including Ceylon and Burma. Diptera Volume V: Culicidae. Tribes Megarhinini and Culicini. Taylor and Francis 1934.

8. World Health Organisation . Entomological surveillance of Aedes spp in the context of Zika virus: Interim guidance for entomologists. WHO 2016.

9. Boyer S, Calvez E, Chouin-Carneiro $T$, Diallo $D$, Failloux AB. An overview of mosquito vectors of Zika virus. Microbes and Infection 2018;20:646-660.

10. Sharma RS, Kaul SM, Sokhay J. Seasonal fluctuations of Dengue vector, Aedes aegypti (Diptera: Culicidae) in Delhi, India. Southeast Asian Journal of Public Health 2005; 36(1): 186-190.

11. Srinivasan R, Mariappan T and Jambulingam P. Defrost water collection trays of refrigerators - A potential breeding habitat of Aedes aegypti in dengue and chikungunya infested areas of Southern India. Dengue Bulletin 2007;31:174-75.

12. Bashar K, Shamsuzzaman M, Chowdhury MAK. Container breeding mosquitoes in Dhaka city, Bangladesh. Bangladesh Journal of Life Sciences 2006;18(1):69-78.

13. Madon M, Mulla MS, Shaw MW, Kluh S, Hazelrigg JE. Introduction of Aedes albopictus (Skuse) in Southern California and potential for its establishment. Journal of Vector Ecology 2002;27:149-154.

14. Hofhuis A, Reimerink J, Reusken C, Scholte EJ, de Boer A, Takken W et al. Hidden passenger of lucky bamboo: Do imported Aedes albopictus mosquitoes cause dengue virus in the Netherlands ? Vector-Borne and Zoonotic Diseases 2009;9(2):217-220.

15. Singh R, Gupta V, Malhotra B, Singh Sujeet, Ravindran $\mathrm{P}$, Meena $\mathrm{D}$ et al. Cluster containment strategy: addressing Zika virus outbreak in Rajasthan, India. BMJ Global Health. 2019;4:e001383. doi:10.1136/bmjgh2018-001383. Available from https://gh.bmj.com/content/4/5/e001383.full 